\title{
MANAGEMENT INTEGRATION PLAN IN A CIVIL CONSTRUCTION COMPANY
}

\author{
Williams Ícaro Miranda da Silva ${ }^{1}$, David Barbosa de Alencar ${ }^{2}$ and Jorge de Almeida Brito Junior ${ }^{3}$
}

1,2,3 Blauro Cardoso de Mattos Higher Education Institute - FASERRA. Manaus-Amazonas, Brazil.

Email: williams.icaro@gmail.com, david002870@hotmail.com,jorgebritojr@gmail.com

Received: Aug 14th, 2019

Accepted: Aug 30th, 2019

Published: December 02 ${ }^{\text {th }}, 2019$

Copyright (C2016 by authors and Galileo Institute of Technology and Education of the Amazon (ITEGAM).

This work is licensed under the Creative Commons Attribution International License (CC BY 4.0).

https://creativecommons.org/licen ses/by/4.0/

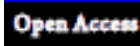

\begin{abstract}
Currently, the subject of Project Management has received great evidence in the business world due to the competition dispute and increasing competitiveness, which makes the business organizations present solutions more quickly and efficiently to external stimuli, in civil construction has been growing the concept of project management with the purpose of having term, quality, profit in the services rendered. With this vision, several tools, methodologies and even organizational entities have been developed with the purpose of ensuring that the projects achieve the expected results. Thus, with several processes and tasks, the project integration management area has high professional relevance, ranging from the elaboration of the scope, through the monitoring and control of the project, and ends in the organization of the final materials, as well as in the lessons learned. Thus, the article will present a project integration plan developed by a construction service provider, the integration plan aims to meet Project management, Time management, Cost management, Quality management and Human resources and their respective controls.
\end{abstract}

Keywords: Project Management; Integration; Management.

\section{INTRODUTION}

The management of integration is the aggregation of methodologies to meet, define, distinguish, combine, unify and structure the project management mechanisms within the groups of project management processes (initiation, planning, execution, monitoring and control and closure). The inverse of the other knowledge areas of project management, the management of integration is an assignment specifies the project manager. Thereby, cannot be attributed to another professional. On the other hand, in managing costs, for example, involve a budget specialist in the management of integration only project manager is able to assume this function with responsibility. After all, he's the only one who has a general understanding of the project and can observe in detail and very well the connections between steps.

Project integration management collaborates effectively in the provision of resources, maintains, demands, provides a plan to achieve the goals of the project, finds solutions to potential problems in the project, and between other important characteristics. To sum up, the major interest of this area of knowledge is certify that all plans are tending towards the same goal of the project, and verify that there are no failures or discordant subjects that need to be worked out. The management of integration, therefore, aims to ensure the understanding between the various areas of knowledge from initiation until the closure of the project.

The Guide Project Management Body of Knowledge (PMBOK) is one of the dominant references in project management, because integrates in a structure that identifies and conceptualizes processes, areas of expertise, tools and techniques. The PMBOK considers managing a project on application of skills, tasks and knowledge in order to meet your requirements. Such management techniques can be applied to all types of projects, regardless of the economic market, the size of the staff involved, deadlines and budgets [1].

This study highlights the implementation of a plan of integration of project used by a service provider of construction business, targeting management tools in order to achieve the objective of the project.

\section{DEVELOPMENT}

The project is as a temporary interest, IE finite. It has, therefore, beginning and end well established and produced to 
achieve a unique objective, that is. a specific effect that makes it unique. The projects are run by people, with obstacles and designed, executed and checked over your lifecycle. So simple, it is possible to affirm that the designs differ from processes and operations, because these latter are continuous and repetitive, while the designs have unique character [2].

For a better sense of the importance of the projects, just understand that for any institution reach its goals, it will need organized efforts. And that is beneficial since the construction of a new factory until the expansion of an operation, for example.

The application of integration management in projects provides excellent benefits for organizations, because we have an upgrade in the communication between the Manager and other employees ceasing rework, personal damage and unnecessary costs. Another benefit to be highlighted is the creative prevention, because it turns out that emerging creative solutions before problems actually happen [3].

The management plan of integration projects is divided into six steps that interact with each other, which are:

- Preparation of the opening of the project: the focus is on the structure of a document that allows the start of the project or a phase. This is the opening of the Term project (OTP), seen as the kick needed to the planning of the work. It also means that all the initial requirements, with stakeholders, must be documented;

- Development of the management plan: The relevance of this step is to determine how it will be conducted at project management. Are documented all the necessary actions to establish, prepare, integrate and manage the plans of all the knowledge areas;

- Guidance and execution management: responsible for conducting Phase, with procedures and guidelines regarding the performance of the tasks laid down. The Manager must monitor the details of the project as the allocation of resources, performance, technical, changes, acquisitions and possible corrective actions;

- Monitoring of work performed: lead and adjust the project to check whether the objectives set at the beginning are being fulfilled. This part is critical to the identification of potential in time, resources, results and project scope;

- Integrated control of changes: in the fifth case, Change requests are analyzed. From a given stream, stimulated and known by all, such requests may be approved or rejected. The great advantage is that the requests are treated in integrated mode, reducing the impacts on final delivery of product or service;

- Closure of the project or phase: the last step takes care of the formal closure of the project (or phase), pointing to the conclusion of all acquisitions, activities and sale of assets. With this, the resources for the job are released and relocated in other actions.

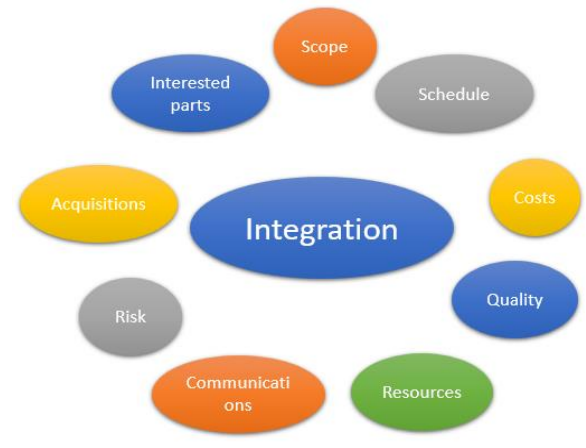

Figure 1: Integration Management-Processes and people. Source: Adapted from [3].
Figure 1 presents the integration of project management that includes coordination of all processes and interfaces of the areas included in your cycle. As a result, organizations tend to reach their goals with greater safety, agility and quality in interlocking steps [4].

\section{METHODOLOGY}

The project aims to carry out the services of building wall in reinforced concrete and rainwater drainage network according to the application requested by the client in a secure manner, with quality and deadline.

Thus, were created control methodologies and project management in order to have a project running efficiently and effectively to ensure customer satisfaction.

The service provider is a company engaged in the business of construction and has an excellent staff trained to consulting and perform your work according to your project.

\section{APLICAÇÃO DO PLANO DE GERENCIAMENTO DA INTEGRAÇÃO DE PROJETOS}

The company developed your Management Plan in order to serve its clients with projects and services aimed at the security and overall quality of the project, with honesty to work and deliver what they promised with transparency in contracts run and respecting the deadline so together with the client, with it aiming to be true in all actions and information.

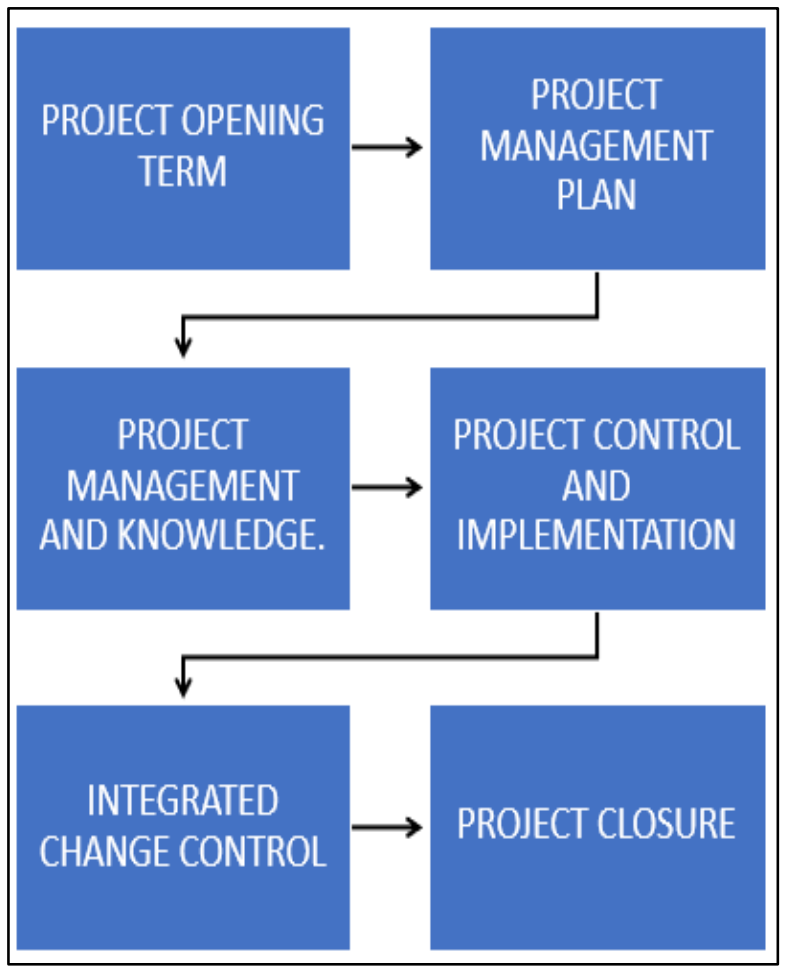

Figure 2: Flowchart (Project Integration Plan). Source: Authors, (2019).

Figure 2 demonstrates each step of the Integration plan used by the service provider in order to use the tool and obtain the best benefit in planning. 
Silva, Alencar and Junior, ITEGAM-JETIA. Vol. 05, No 20, pp 24-28. December, 2019.

Table 1: Project Opening Term.

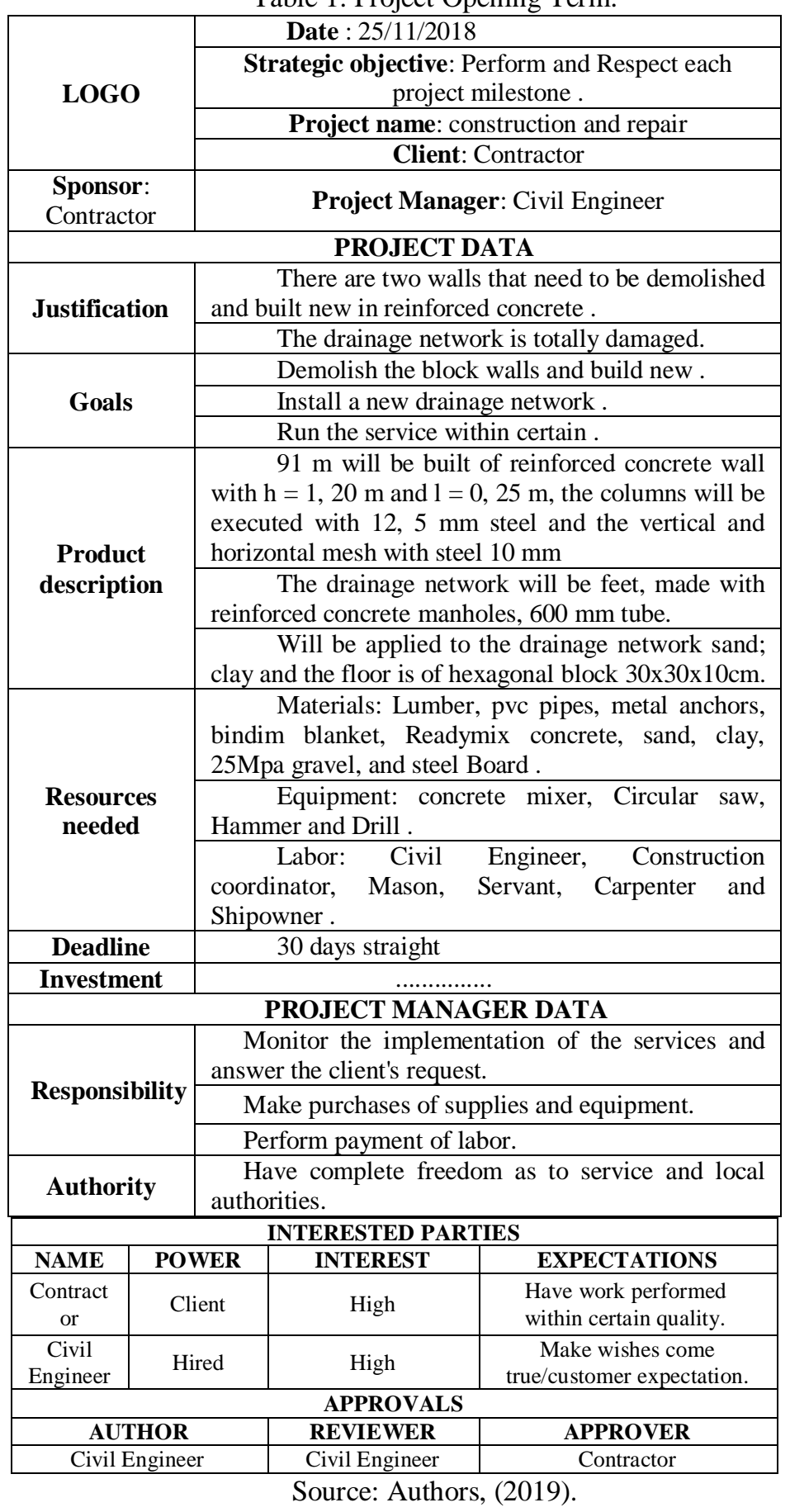

According to table 1, it is possible to understand how the application of the term project opening, it informed the project data containing your background, purpose, description, required resources, term, investment, the parties concerned and their responsibilities.

Table 2: Project Management Plan.

\begin{tabular}{|c|c|c|}
\hline \multicolumn{3}{|c|}{ PROJECT MANAGEMENT } \\
PACKAGE & DESCRIPTION & RESPONSIBLE \\
\hline $\begin{array}{c}\text { Project } \\
\text { management } \\
\text { and } \\
\text { execution of } \\
\text { the services }\end{array}$ & $\begin{array}{c}\text { Application of knowledge, } \\
\text { skills and techniques in the } \\
\text { execution of the contracted } \\
\text { activities to achieve the set } \\
\text { goals of the project based on } \\
\text { the existing standards to } \\
\text { achieve quality of service. }\end{array}$ & $\begin{array}{c}\text { Project Manager } \\
\text { and Civil } \\
\text { Engineer . }\end{array}$ \\
\hline
\end{tabular}

\begin{tabular}{|c|c|c|}
\hline analysis & $\begin{array}{c}\text { Survey and study in place for } \\
\text { the development of activities } \\
\text { and services. }\end{array}$ & $\begin{array}{c}\text { Construction site } \\
\text { coordinator. }\end{array}$ \\
\hline $\begin{array}{c}\text { Procurement } \\
\text { of materials } \\
\text { and } \\
\text { equipment }\end{array}$ & $\begin{array}{c}\text { Quote, analysis, purchase and } \\
\text { delivery of equipment and } \\
\text { supplies required. }\end{array}$ & $\begin{array}{c}\text { Construction site } \\
\text { coordinator. }\end{array}$ \\
\hline Development & $\begin{array}{c}\text { Specifications, testing, } \\
\text { documentation and control the } \\
\text { executions of services. }\end{array}$ & Civil Engineer. \\
\hline Deployment & $\begin{array}{c}\text { Execution of side Walls and } \\
\text { drainage network. }\end{array}$ & Skilled labor. \\
\hline Closure & $\begin{array}{c}\text { Adjustment, correction and } \\
\text { evaluation of the project. }\end{array}$ & $\begin{array}{c}\text { Project Manager, } \\
\text { Civil Engineer } \\
\text { and coordinator } \\
\text { of works. }\end{array}$ \\
\hline Delivery & $\begin{array}{c}\text { Deliver project/completion of } \\
\text { service contract by the } \\
\text { customer. }\end{array}$ & Project Manager. \\
\hline
\end{tabular}

Source: Authors, (2019).

The table 2 presents the project management plan, it was informed the conduce of the project, stating how the project will be executed, managed, monitored and closed.

The project manager together with your strategic team (Civil Engineer and coordinator of works) will make available to the client monitoring reports and that will contain the information about the term, and elapsed time of the work, in case of change in scope the project manager must come in direct contact with the client to the appropriate approvals and knowledge.

As for service, it is your responsibility to follow up and guide the Civil Engineer labor to perform the service in accordance with the current standards of ABNT, the safety of its employees is applied in your scope.

The modifications shall be adopted in accordance with the procedure laid down in the Integrated Control of changes and will only be carried out with the necessary approvals delivered with the proper authorization of the client.

In the context of the project, changes may occur for various reasons, the factors that cause changes may be:

- Changes in the constructive process defined in project;

- Changes requested by Stakeholders to increase or reduce functionality in product design;

- Changes requested by the client;

- Changes proposed by the project team in order to meet the technical particularities that may arise during the development;

- To enter/change a new component (software or hardware) in order to meet the needs of the business.

These variations impact absolutely in scope, time and quality of the project. In order to establish clear procedures and formal, if necessary the creation of Change management process.

This procedure is a collection of documented devices that define the steps through which the official documents of the design can be changed. This process includes working papers, monitoring systems, scope, various requests and approval levels necessary for authorizing changes.

These "Changes" must also be documented so as not to cause further problems to the project and the client. 
Table 3: Project Management and Knowledge.

\begin{tabular}{|c|c|c|}
\hline \multicolumn{3}{|c|}{ PROJECT KNOWLEDGE } \\
\hline FUNCTION & PROFILE & $\begin{array}{l}\text { COMP } \\
\text { ANY }\end{array}$ \\
\hline $\begin{array}{l}\text { PROJECT } \\
\text { MANAGER }\end{array}$ & $\begin{array}{c}\text { Civil Engineer, knowledge of project } \\
\text { management methodology, experience in } \\
\text { infrastructure projects, Supra and } \\
\text { drainage Network structure, } \\
\text { communication skills and interpersonal } \\
\text { skills }\end{array}$ & HIRED \\
\hline $\begin{array}{l}\text { CONSTRUC } \\
\text { TION SITE } \\
\text { COORDINA } \\
\text { TOR }\end{array}$ & $\begin{array}{c}\text { Civil Engineer, experience in } \\
\text { infrastructure projects, Supra and } \\
\text { drainage Network structure, experience in } \\
\text { purchasing/procurement of inputs and } \\
\text { equipment, communication skills and } \\
\text { interpersonal skills. }\end{array}$ & HIRED \\
\hline MASON & $\begin{array}{l}\text { Construction experience on reinforced } \\
\text { concrete. }\end{array}$ & HIRED \\
\hline SERVANT & $\begin{array}{l}\text { Construction experience on reinforced } \\
\text { concrete. }\end{array}$ & HIRED \\
\hline $\begin{array}{r}\text { POINT } \\
\text { GUARD } \\
\end{array}$ & $\begin{array}{l}\text { Experience in building in reinforced } \\
\text { concrete, steel structure frame. }\end{array}$ & HIRED \\
\hline $\begin{array}{l}\text { CONCRETE } \\
\text { MIXER } \\
\text { OPERATOR } \\
\end{array}$ & $\begin{array}{c}\text { Experience in concrete walls, pillars, } \\
\text { beams and match the stroke set by Civil } \\
\text { Engineer. }\end{array}$ & HIRED \\
\hline $\begin{array}{l}\text { CLEANING } \\
\text { ASSISTANT }\end{array}$ & $\begin{array}{c}\text { Deliver project/completion of service } \\
\text { contract by the customer, clean and } \\
\text { organized }\end{array}$ & HIRED \\
\hline
\end{tabular}

Source: Authors, (2019).

The table 3 displays the specifications and guidelines regarding the implementation of the activities to be carried out in project.

Monitoring and control as the implementation of the project will be of full responsibility of the Civil Engineer, being responsible in transmitting such information to the project manager.

Team members will be subject to periodic review and performance that should follow the following indicators, such evaluations will be performed by the Civil Engineer, will apply a 0 to 10 for each indicator set in the control of execution of the Project.

The survey of materials, supplies, equipment, effective will be done daily for the General control of the terms that occur in the work.

Table 4: Control and Execution of the Project.

CONTROL OF THE EXECUTION OF THE PROJECT

\begin{tabular}{|c|c|c|}
\hline \multicolumn{2}{|c|}{ CONTROL OF THE EXECUTION OF THE PROJECT } \\
\hline BOOKMARK & DESCRIPTION & PERIOD. \\
\hline COMMITMENT & $\begin{array}{c}\text { Involvement in the activities of the } \\
\text { project developing and improving } \\
\text { its capabilities }\end{array}$ & DIARY \\
\hline $\begin{array}{c}\text { CONFLICT } \\
\text { RESOLUTION }\end{array}$ & $\begin{array}{c}\text { Ability to solve problems with } \\
\text { people involved in the project }\end{array}$ & DIARY \\
\hline COMMUNICATION & $\begin{array}{c}\text { Interaction and objectivity on the } \\
\text { information generated and } \\
\text { exchanged during development of } \\
\text { the project. }\end{array}$ & DIARY \\
\hline $\begin{array}{c}\text { DEADLINES AND } \\
\text { COSTS }\end{array}$ & $\begin{array}{c}\text { Ability to manage time and costs in } \\
\text { the project }\end{array}$ & DIARY \\
\hline $\begin{array}{c}\text { CREATIVE AND } \\
\text { INNOVATIVE }\end{array}$ & $\begin{array}{c}\text { Present attitudes and ideas different } \\
\text { from routine but that present } \\
\text { positive results. }\end{array}$ & DIARY \\
\hline $\begin{array}{c}\text { CHANGE } \\
\text { MANAGEMENT }\end{array}$ & $\begin{array}{c}\text { Flexibility in the face of changing } \\
\text { situations or decisions }\end{array}$ & DIARY \\
\hline
\end{tabular}

Source: Authors, (2019).
In table 4 are the way to control the quality of the project was defined through the Scope, requirements and Costs, indicators, metrics and meta.

The Change request is used whenever you identify a change and that can be incorporated into the Project.

Any Intervenor may detect a need for change in the execution of the project. In any case, the project manager is responsible for drawing up the standard form of Change request. It is the responsibility of the project manager together with your team to evaluate the impact of strategic changes, align, and get the best way for your deployment, checking previously if the change is really needed.

Once detected the change and displayed on the form, the project manager will evaluate the impact on the project. The project manager will have up to 1 (one) working day to perform the analysis of change, showing the delivery of same. The evaluation process will be observed the following:

- Change in tasks that were hit so far;

- Change in the agreed delivery times;

- Resources needed to carry out the changes;

- The pricing changes, reflected in the form.

Done all these procedures, the project manager will submit your request or request for change to the client and should review and approve such request (the change will only be carried out with the approval of the customer).

Table 5: Form (Change request).

\begin{tabular}{|l|l|}
\hline \multirow{2}{*}{\multicolumn{1}{|c|}{ LOGO }} & DATE - \\
\cline { 2 - 2 } & $\mathrm{N}^{\circ}-$ \\
\cline { 2 - 2 } & PROJECT NAME - \\
\cline { 2 - 2 } & START AND FINISH - \\
\hline Change Requested By & \\
\hline Date of Request & \\
\hline Information About the Change \\
\hline $\begin{array}{l}\text { Description of the Proposed } \\
\text { Amendment }\end{array}$ \\
\hline $\begin{array}{l}\text { Description of the Reasons for } \\
\text { the Amendment }\end{array}$ \\
\hline $\begin{array}{l}\text { Impacts if the Change is not } \\
\text { Implemented }\end{array}$ \\
\hline Alternatives to Consider \\
\hline Change in Cost \\
\hline Budgeted Total Cost \\
\hline Total Revised Cost \\
\hline NOTE : \\
\hline \multicolumn{2}{|c|}{ APEPARATION } \\
\hline DATE : \\
\hline \\
\hline DATE : \\
\hline
\end{tabular}
Source: Authors, (2019).

The table 5 presents a Change request form, it was created with the purpose to register the entire change, identify the impact, time, costs, determine the best alternative to effect change, and obtain the approval of Actors previously, before starting any action associated with.

The project will be considered as terminated only after formal approval between the project manager and client, which will see through the project documentation if the deliveries actually were performed according to the specified and all items in the 
scope were contemplated. To do so, will be completed the term of termination of the project below, which should be signed and filed in the finally Project documentation the project is only terminated with the approval of the client.

Table 6: Project Closure Document.

\begin{tabular}{|c|c|}
\hline \multicolumn{2}{|c|}{$\begin{array}{l}\text { PROJECT CLOSURE DOCUMENT } \\
\end{array}$} \\
\hline \multirow{4}{*}{ LOGO } & DATE - \\
\hline & $\mathrm{N}^{\circ}-$ \\
\hline & PROJECT NAME - \\
\hline & START AND FINISH - \\
\hline \multicolumn{2}{|c|}{ DELIVERIES } \\
\hline \multirow[t]{2}{*}{ SERVICES } & DELIVERY DATE \\
\hline & ACCEPTED \\
\hline CLIENT & PROJECT MANAGER \\
\hline
\end{tabular}

Source: Authors, (2019).

\section{RESULTS AND DISCUSSION}

The Integration Plan of construction and repair Project was developed in a coherent and effective to meet best the client and the contractor get maximum control of your services and deadlines.

Therefore, the contractor will meet both customer expectations as the expectation of the same run their services safely and in accordance with the regulatory standards.

The project seeks to meet the project management, time management, Cost management, Quality management and Human Resources and their respective controls.

The more control we have over our process, more savings and satisfaction to meet the client will be serviced efficiently facilitating the execution of the services of its employees and answering directly the deadline agreed between contractor and Signed.

\section{CONCLUSIONS}

Project management is increasingly in notoriety on universal vision. The deprivation rapid results associated with the increased competition and difficulty of the business world makes the competence in project management is an important success factor for the Organization.

These elements imply still on duty if organizations build capacity to coordinate, manage and control their activities in order to respond in the best way possible, to external stimuli. Such peculiarities are closely linked to project management and to the success of the implementation of the organizational strategies.

In this way, projects can be defined as a way to plan, execute and control actions aimed at the implementation of strategies. The better the management of these, the better the results and benefits achieved.

The result obtained by applying the integration management was satisfactory, as the work occurred in accordance with the planning meeting customer expectation, the only step that management was not used was the request control change.

Through from study, available to other organizations in this segment, civil construction, a plan of integration projects that do not demand large or expensive resources, not requesting the hiring of consultants, experts, equipment for your deployment.

\section{ACKNOWLEDGMENTS}

First the God who always blessed me of grand way, putting the angels in my life so I can accomplish my goals.

My father Luzinaldo Peixoto da Silva that with your unconditional love, lost nights of sleep, resigned for goals I could reach my, turned me into a man of character and success.

I thank the professionals who have contributed to the realization of this work and the Institute of Higher Education Blauro Cardoso de Mattos - FASSERA.

\section{REFERENCES}

[1] Mancuso, Rafael. Project Management, Based on PMBOK SYSTEM: A case study in an electronics industry. School of technology (FATEC) Heron. SÃO PAULO, 1-16.

[2] Rockcontent - Projectbuilder. What is PMBOK?, 2015. Available in: <https://www.projectbuilder.com.br/blog/o-que-epmbok/>. Accessed in: 11 July 2019.

[3] Carlos - Projectbuilder. What is it and how does the integration management of projects? 2019. Available in: $<\quad$ https://www.projectbuilder.com.br/blog/gerenciamento-deintegracao/>. Accessed in: 12 July 2019.

[4] Escritório de Projetos. Project integration management, 2019. Available in: <https://escritoriodeprojetos.com.br/gerenciamentoda-integracao-do-projeto>. Access in: 13 July 2019.

[5] Almeida, Josie. Integration of projects in the engineering phase. Article Planning engineering, IETEC. São Paulo.

[6] Devmedia. Project Integration management, 2019. Available in: < https://www.devmedia.com.br/gerenciamento-da-integracaodo-projeto/28348 >. Access in: 13 July 2019.

[7] EUAX. Integration management: what it is and how to do it in steps 7, 2013. Available in:< https://www.euax.com.br/2019/04/gerenciamento-daintegracao/>. Accessed in: 13 July 2019.

[8] Farias, Raileide. The management of integration as success factor in project management. Work of conclusion of course (graduate), MBA in project management, Fundação Getúlio Vargas. Salvador, 2018.

[9] Luz. The first steps of a project: integration management, 2018. Available in: < https://blog.luz.vc/o-que-e/gerenciamento-deintegracao-na-gestao-de-um-projeto/>. Accessed in: 10 July 2019. 